\title{
Latin America and the Caribbean Meet the Post- Soviet World: Can Pro Forma Diplomacy Evolve?
}

\author{
Wilder Alejandro Sanchez, USA
}

Correspondence: wilder.a.sanchez@gmail.com

\begin{abstract}
The 33 countries that constitute Latin America and the Caribbean and the 11 countries of the former Soviet Union (not counting the Russian Federation and the three Baltic nations) conform 44 states which are, with a few exceptions, on the periphery of global geopolitical affairs, with limited international influence or at the mercy of conflicts that have disrupted their internal balance and international image in the past decade. While the topic of how peripheral nations and regions interact with each other has been analyzed in academia, in-depth studies about relations between these specific regions are very limited and scarce. This paper seeks to fill in that gap by providing recent examples on issues like trade and high-profile diplomatic visits between Latin American and Caribbean governments with their post-Soviet counterparts. Moreover, I will discuss the issue of the location (or lack thereof) of embassies, a topic not discussed in the consulted literature, as an example of how governments from peripheral states and limited budgets decide where to open an embassy. It is proposed here that the 44 states that make up Latin America, the Caribbean, and the post-Soviet world will remain cordial and friendly strangers for the foreseeable future. A lack of grand-strategy vision, with a few exceptions, is a major hindrance to stronger relations between these states. The most plausible scenario is bloc-to-bloc trade agreements; however, the COVID-19 pandemic and more pressing issues that these countries face mean that treaties with geographically distant states that are not trading partners or potential sources of financial aid are not regarded as priorities.
\end{abstract}

\section{KEYWORDS}

Latin America, Caribbean, post-Soviet World, Diplomacy, Trade, Central Asia, Caucasus 
Relations between Latin American and Caribbean nations with the post-Soviet world have slowly developed since the dissolution of the Union of Socialist Soviet Republics (USSR). While there have been some significant initiatives between these geographically distant regions, such as the recognition of Abkhazia and South Ossetia by the Bolivarian Republic of Venezuela and the Republic of Nicaragua, in addition to new commercial projects, like the Plurinational State of Bolivia exporting meat to the members of the Eurasian Economic Union, the prospect for greater integration in the foreseeable future between these regions looks bleak.

This is primarily the result of a lack of foresight by most governments in the Western Hemisphere and Eurasia to approach their distant counterparts as (most) regional governments on both sides of the planet have foreign policies that are primarily based on regional objectives. Nevertheless, the same lack of strong relations allows for an academic analysis on what issues can potentially bring together these geographically distant governments.

This paper aims to provide further research in the field of relations between these (mostly) developing states. While academic research already exists, the author argues that it is too limited; for example, no source that the author consulted discusses the number (and role) of embassies. Similarly, this research provides recent trade data, diplomatic meetings, and also public diplomacy initiatives, an issue which is similarly not deeply analyzed in the existing literature. As the globalized world becomes more interconnected, nations, even small and medium powers, should be encouraged to look for partners and allies past the horizon of their respective regions.

\section{Research Design}

Relations between Latin American and Caribbean states with post-Soviet states are limited; hence there is not much hard data available to analyze. On the other hand, since there are 33 countries in Latin America and the Caribbean, and 11 in the post-Soviet world, not counting the Russian Federation and the Baltic states, there is a plethora of potential combinations between these 44 nations, in addition to regional blocs, that could occur in the future. ${ }^{1}$ In this analysis, we will focus on the past decade of relations between these regions due to space limitations and also a lack of significant information dating back to the 1990s when post-Soviet states commenced establishing relations with the rest of the world.

In order to find information about initiatives such as agreements, government data about trade, diplomatic visits, and weapons transfers, this analysis carried out exhaustive research in the various languages spoken in these regions, such as Spanish, Romanian, Russian, Ukrainian, Portuguese, and English, the lingua franca of international relations these days.

Given the vast numbers of countries that fall under the umbrella of this essay, 44 in total, in order to illustrate the situation better, this analysis will carry out brief case studies. The goal is to use specific examples to highlight and analyze which objectives and interests guide countries in region $\mathrm{X}$ to approach their counterparts in region $\mathrm{Y}$.

1 The author will not include the three Baltic nations. Baltic nations are not members of blocs like the Commonwealth of Independent States or the Eurasian Economic Union but rather are part of the European Union and the North Atlantic Treaty Organization. Similarly, Russia will not be discussed as there is plenty of literature available about Moscow's relations with the Western Hemisphere. 
As D. Walton argues, "all too often even the largest Eastern Eurasian states are dismissed as having merely 'regional' interests, the underlying assumption being that they do not have worldwide interests because they do not presently have global influence comparable to that enjoyed by the United States," or other world powers and major blocs. ${ }^{1}$

This is because "peripheries have a significantly weaker ability to amass and project power, and they are often seen as a mere theatre of operations." ${ }^{2}$ Indeed, many authors dismiss the relevance of medium and small nations that have limited influence in global geopolitics. For example, in an essay on the theory of geopolitics and Latin America, P. Dallanegra argues that "the region [Latin America - author] operates as a subordinated periphery, rather than being part of the [global geopolitical - author] system," ${ }^{3}$ adding that "peripheral nations in general, and Latin America in particular, have looked for ways to have a bigger role in international affairs, particularly regarding decision making" and altering the global order. ${ }^{4}$ Latin America, the Caribbean, and post-Soviet nations are viewed as being peripheral nations, with limited roles in global geopolitics - for example, Latin America and the Caribbean are generally viewed as "Washington's Backyard," while many post-Soviet nations are Russia's "Near Abroad," implying that these nations are firmly within the sphere of influence of global powers. While confirming or denying this assumption is not part of our analysis, the overall argument here is that, just because this may be true, it does not mean that these 44 states cannot have ambitious foreign policies that do not depend on ties with neighboring Washington, Moscow or Beijing, not only to achieve an emerging role in global geopolitics but also to increase their global footprint and attain domestic objectives by making new allies in geographically distant areas. The obvious question is: why do small states might attempt to develop relations with other small states (not only regional powers) in far-away regions?

\section{Literature Review}

In recent years there has been slow growth in the literature about Latin America's relations with non-traditional partners. For example, a number of books have been published that discuss Latin America's relations with the Arab World. These include F. Saddy's The Arab World and Latin America: Economic and Political Relations in the TwentyFirst Century 5 and M. T. Kuri's Latin American Foreign Policies Towards the Middle East. ${ }^{6}$ There is also a robust amount of literature regarding Brazil's foreign policy towards Africa, a longtime area of interest for Brasilia.

On the other hand, the post-Soviet region is even more geographically distant than the Middle East, and as geography still matters, even in a globalized world, there is very little academic work about Latin America's overall relations with the post-Soviet world in general. One recent work, Eurasia y América Latina en un mundo multipolar, 
was published by the Argentine-based research center Coordinadora Regional de Investigaciones Económicas y Sociales (CRIES) in 2020. ${ }^{1}$ However, as well written as this book is, most of it is devoted to relations between Russia and China with Latin America and the Caribbean. Only the final chapter really analyzes relations between post-Soviet states, apart from Russia, with the Western Hemisphere.

Similarly, Eurasia-Latin America Strategic Engagement and Comparative Perspectives in Politics and Economics ${ }^{2}$ is a very well researched monograph published by Kazakhstan's Ministry of Science and Education and L.N. Gumilyov Eurasian National University the fact that a Kazakhstani center of education published this work highlights NurSultan's interest in approaching Latin America and the Caribbean, an objective not matched, yet, by other Central Asian governments. However, out of the 11 chapters that constitute this monograph, five are about Turkey, one is about Iran, and one is about Russia, which means only four chapters are left for analyses of post-Soviet nations.

There is some country-oriented work, as an essay on Argentina-Kazakhstan relations, written by two academics, one from each country that was published by a Kazakhstani Institute for Diplomacy. ${ }^{3}$ Similarly, a 2016 essay published in a journal of the Argentine University Univeridad Nacional de Lomas de Zamora discusses the potential for closer relations between the Eurasian Economic Union and the South American trade bloc Mercado Común del Sur (MERCOSUR) by using the cordial relations between Argentina and Russia as a link between the two blocs. ${ }^{4}$

Unfortunately, the analysis on Argentine-Kazakh relations is mostly a summary of bilateral initiatives and meetings between officials from both nations, with the conclusions suggesting that the two governments should "[develop - author] a well-conceived, consensus-driven Argentinean-Kazakhstani agenda and framework aiming at enhancing the collaboration [of the - author] finance sector and channelizing it for the development of bilateral relations." ${ }^{5}$

As for Russian-language articles, a 2017 essay in the Journal of Political Research discussed Ukraine's relations with Latin America and highlighted how Kyiv does not see the region as a foreign policy priority. ${ }^{6}$

While a lack of academic analyses on this issue can be frustrating, this situation also provides a great opportunity to break new ground, analyze the raw data available, establish new paradigms and offer policy suggestions. For example, this article will discuss embassies, not simply due to their role as traditional agencies to bring governments together, but also because the location of embassies is a good method to understand whether countries $A$ or $B$ from region $X$ is regarded as important, in a general sense of the word, by country $C$ from region $Y$. Considering the often-

2 Ariel González Levaggi, Akbota Zholdasbekova, and Nilüfer Narlı, "Eurasia-Latin America Strategic Engagement and Comparative Perspectives in Politics and Economics," accessed October 4, 2021, https://www.researchgate.net/publication/325360555_ Eurasia-Latin_America_Strategic_Engagement_and_Comparative_Perspectives_in_Politics_and_Economics.

3 Botta, Zholdasbekova 2020.

4 Gustavo Carrizo Adris, and Alexandra Eropunova. “La Unión Económica Euroasiática (UEEA) y las Relaciones Interbloques El Memorándum de Entendimiento con el MERCOSUR (The Eurasian Economic Union (EAEU) and Inter-Bloc Relations The Memorandum of Understanding with MERCOSUR)," accessed October 5, 2021, http://www.derecho.unlz.edu.ar/revista_ juridica/03/2.pdf/.

6 Курылев, Мачавариани 2017. 
limited financial resources of many of these governments, establishing an embassy in a geographically distant region is a huge commitment and suggests which countries are regarded as priorities by others.

\section{Latin America and the Caribbean Meet the post-Soviet World}

Since the end of the Cold War and the fast pace of globalization, thanks to the development of better communication and transportation technologies, we have seen a growth in the interaction between regions that did not historically interact with one another. This does not mean that before 1991, the interaction between geographically distant governments did not occur. For example, during the Cold War, the Non-Aligned Movement was created; its members came from the developing world across Latin America, the Caribbean, the newly independent African states, the Arab World, and Asia. Similarly, under the umbrella of developing ties with nations that share a similar colonial past, the government of Brazil approached the newly independent African nations in the 1960s and the 1970s.

"The end of the Cold War threw the study of international relations into a state of still unresolved uncertainty and flux, as we considered how to move away from serious ideological tension to increased international cooperation, in a world suddenly and dramatically transformed," explains J. Haynes. ${ }^{1}$ In the post-Cold War era, there have been more attempts to have geographically distant nations increase relations and form partnerships and alliances. Case studies conducted by scholars tend to focus on global powers, such as the People's Republic of China, the Russian Federation, the United States, or a bloc like the European Union, however regional and rising powers have also attempted to become involved in such processes. For example, BRICS brings together Brazil, Russia, India, China, and South Africa as a sort of trade and the diplomatic bloc. Similarly, the Ibero-American summit is a (traditionally) annual meeting of the heads of state of the Spanish- and Portuguese-speaking nations of the Americas and Europe, namely Portugal and Spain. Moreover, had it been ratified, the Trans-Pacific Partnership would have created a free trade area among states close to the Pacific Ocean, bringing together nations like Brunei and Peru.

Relations between the regions discussed in this study remain limited, and there is no overall grand strategy from either side, whether at the state or bloc level, to increase relations, except for a few very specific examples. This is hardly surprising. Latin America and the Caribbean are not united blocs, as evidenced by the ongoing crisis regarding Venezuela, which has divided the Western Hemisphere between governments that support President N. Maduro, while others, led by the United States, support President J. Guaidó. ${ }^{2}$

The post-Soviet world is similarly divided. While some blocs exist like the Russianled Eurasian Economic Union, ${ }^{3}$ the Collective Security Treaty Organization, ${ }^{4}$ or the GUAM

2 N. Maduro's close allies in the Western Hemisphere are Cuba, Nicaragua, Argentina, Trinidad and Tobago. Regional states that recognize Guaidó include Brazil, Canada, Chile, Colombia, Peru, the United States, among others. 
Organization for Democracy and Economic Development ${ }^{1}$, there is no organization that brings together all post-Soviet states, nor is there a Central Asian union. Moreover, tensions between Russia with nations like Georgia, Ukraine, and even the Republic of Moldova (depending on which political party rules the country) mean that these governments will not support a foreign policy strategy that originates in Moscow.

The other issue is capabilities. The 44 nations that are analyzed in this essay are not particularly rich or highly developed nations. For example, out of all these states, only five, Chile, Colombia, belong to the Organization for Economic Co-operation and Development (OECD), which has the majority of most developed nations as members. ${ }^{2}$ Of course, economically strong nations with an ambitious foreign policy like Kazakhstan are not the organization's members, but the OECD member list gives us an idea of the overall economic situation.

Limited financial resources mean that not much of the state's budget can be devoted to opening embassies across the world or have an active extra-regional foreign policy. Thus, some of the poorer states, like Haiti and Kyrgyzstan, will have very limited foreign policy ambitions, meaning that approaching countries on the other side of the planet will not be their priority unless this promises a major trade agreement or other types of assistance - hence many impoverished Latin American and Caribbean countries are actively befriending investment-prone, rich China, rather than poor, post-Soviet state $\mathrm{X}$ or $\mathrm{Y}$.

In other words, there are only a few nations in the Western Hemisphere and the post-Soviet world that are attempting to approach their distant counterparts. The result is a mixed set of initiatives from both sides, with no clear pattern or grand strategy. The following sections will enumerate and analyze recent developments in order to attempt to predict the future.

\section{What is the Significance of an Embassy?}

Public diplomacy is a critically important task of embassies, as "in hopes to promote a positive image and build friendly relations, embassies regularly involve themselves in work which promotes their countries' image and wishes for continued/ increased cooperation and stability." ${ }^{3}$ While there has been a lot of discussion in recent years about how globalization and communication technologies are affecting the role of diplomats and the future of embassies, these institutions remain relevant and necessary. ${ }^{4}$

An in-depth analysis of which Latin American and Caribbean states have embassies in post-Soviet nations, and vice-versa, is not the objective of this essay; however, a quick overview provides some interesting data.

In order to make it easier for the reader to follow the data, I have created two graphs: Table 1 lists the embassies of post-Soviet nations (plus Mongolia) in Latin

2 "Member Countries," Organisation for Economic Cooperation and Development, accessed February 10, 2021, https://www.oecd. org/about/members-and-partners/.

3 Dror Ruben Zilberboim, "Roles of Embassies," Dror Ruben Zilberboim, August 24, 2018, accessed January 13, 2021, https:// medium.com/@drorreuvenzilberboim/roles-of-embassies-5b63e4423c0.

4 Moira Gallaga, “Do we still need embassies?" The Diplomat, September 4, 2013, accessed January 20, 2021 https://thediplomat. com/2013/09/do-we-still-need-embassies/. 
America, while Table 2 lists the embassies of Latin American nations (including Cuba and the Dominican Republic) in post-Soviet countries (plus Mongolia). Due to space reasons, charts are not provided for the English-Speaking Caribbean nations, Haiti and Suriname, though a perfunctory analysis could not find any Caribbean embassy in post-Soviet states apart from Russia - though Georgia's embassy in Brazil is concurrent to the Caribbean Community, Guyana, Trinidad and Tobago, and Suriname. Moreover, the charts do not lists consulates, honorary consulates, or other diplomatic missions.

Some Latin American states have a significant diplomatic representation in the postSoviet world. As Table 2 demonstrates, Brazil, one of Latin America's powerhouses, has several embassies, including in the three Caucasus nations, Ukraine, and several concurrent ones in Central Asia out of Kazakhstan.

Concurrent embassies are used by other governments to maintain diplomatic representation. For example, Argentina has embassies in Armenia, Azerbaijan, and Georgia (based out of Turkey). Other Argentine embassies are concurrent with neighboring post-Soviet states: the embassy in Russia oversees ties with Belarus, Kazakhstan, Kyrgyzstan, Turkmenistan, and Uzbekistan. Similarly, the embassy in Romania deals with Moldova; the embassy in China deals with Mongolia, and the embassy in Pakistan deals with Tajikistan. Chile is in a similar situation as it relies on concurrent embassies: the embassy in Poland oversees Ukraine, and the embassy in Russia oversees Kazakhstan. Meanwhile, Mexico has embassies in Azerbaijan, Russia, and Ukraine; while, Costa Rica has an embassy in Azerbaijan.

As Table 2 demonstrates, Latin American nations seem to focus on Eastern European states (except for Moldova) and the Caucasus, while diplomatic representation in Central Asia and Mongolia remains very limited outside of Kazakhstan. Additionally, there are several countries that do not have embassies in the post-Soviet world. These include the Central American states (apart from Costa Rica's embassy in Azerbaijan, which is an exception to the rule), Bolivia, Ecuador, Paraguay, Peru, and Uruguay. Finally, it is worth noting that while Nicaragua and Venezuela recognize Abkhazia and South Ossetia as independent states, there are no embassies in these two regions. Venezuela's embassy in Russia is concurrent with both of them.

Regarding diplomatic representations from post-Soviet states in Latin America, the legacy of the Soviet Union continues to have consequences today. In other words, it is no surprise that many post-Soviet nations have embassies in Cuba. Table 1 shows how Ukraine has diplomatic offices in Argentina, Brazil, Cuba, Dominican Republic, Mexico, Peru; and concurrent embassies that oversee Bolivia, Chile, Costa Rica, Ecuador, El Salvador, Guatemala, Honduras, Nicaragua, Panama, Paraguay, Uruguay, and Venezuela, essentially the entire region. As for Belarus, the country has embassies in Argentina, Brazil, Cuba, Ecuador, and Venezuela. (There have been reports that Kyiv has planned to open an embassy in Colombia, but the said embassy is not listed in the ministry of foreign affairs; hence it is not listed in the Tables).

As for the Caucasus, Armenia and Georgia have a fairly strong diplomatic representation, with Tbilisi relying heavily on concurrent embassies. On the other hand, Azerbaijan has embassies in only three nations: Argentina, Brazil, and Mexico, with diplomatic offices in Chile, Colombia, Cuba, Peru, and Uruguay.

The situation dramatically changes when one discusses Central Asia, as the only country with diplomatic offices is Kazakhstan, which is unsurprising given its ambitious 


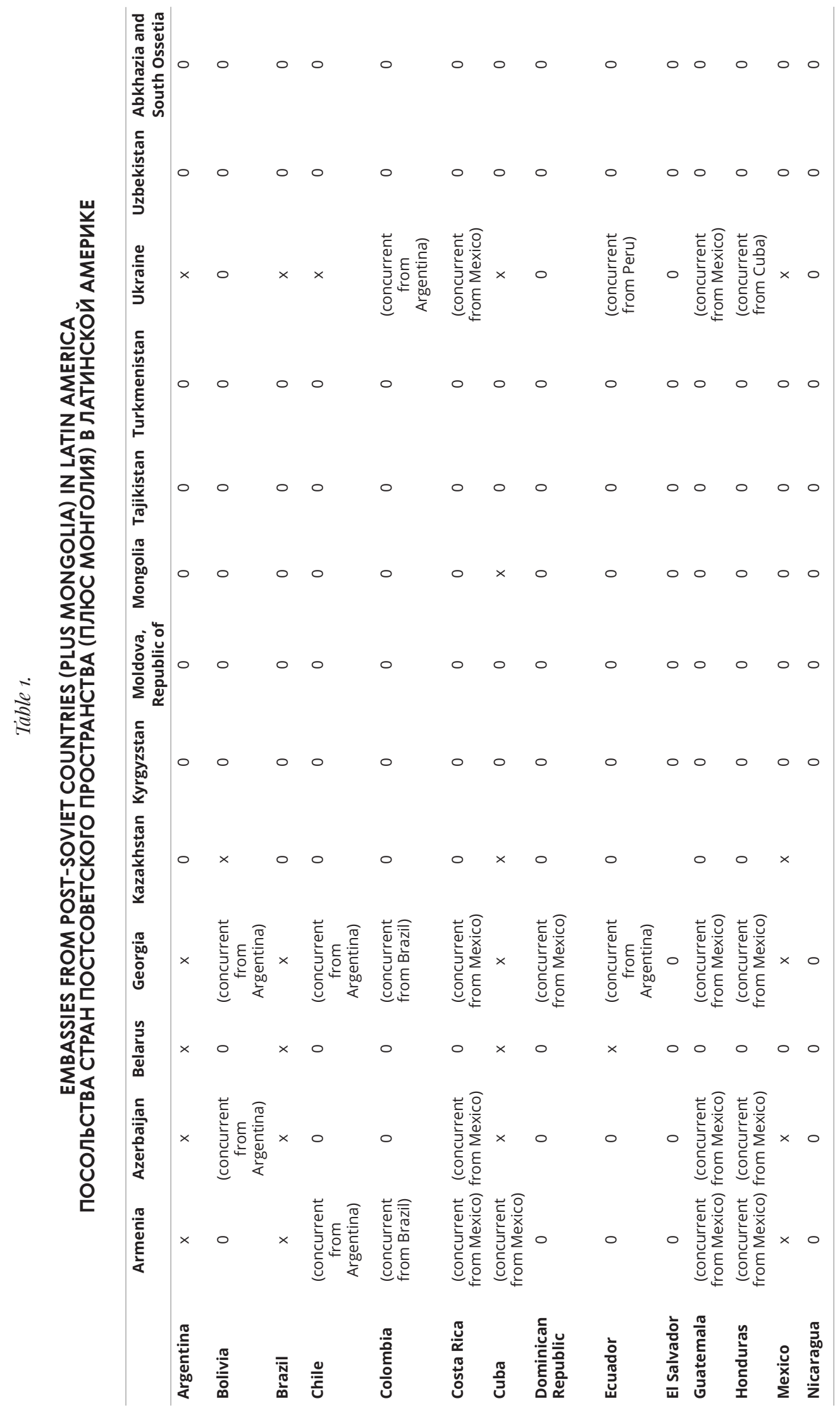




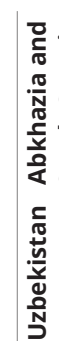

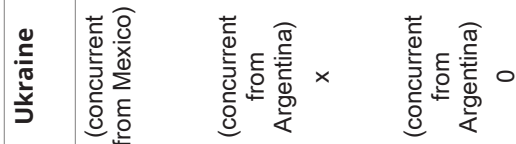

悉

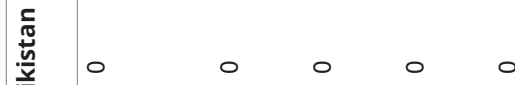

ֻั

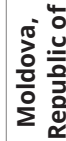

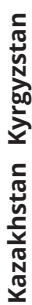

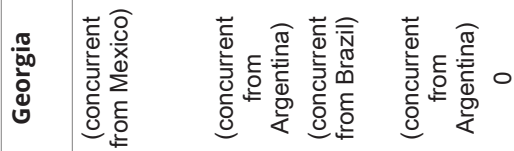

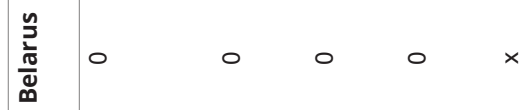

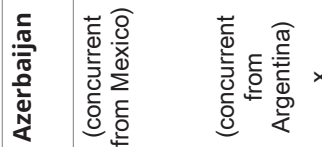

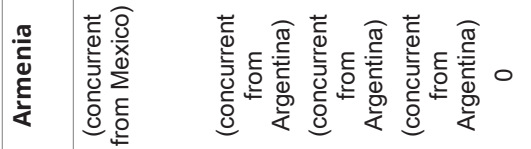

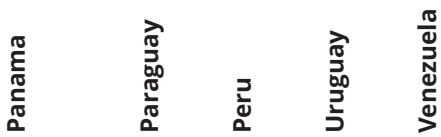
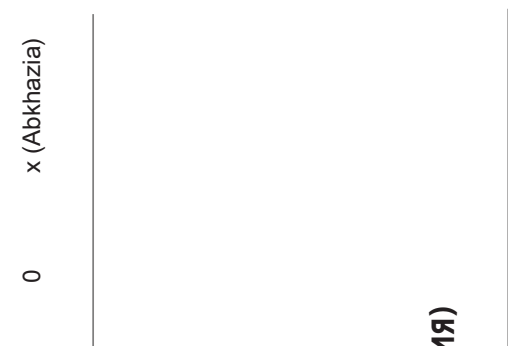

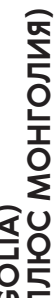

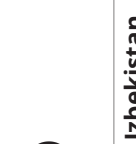
든

电

离

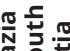

등

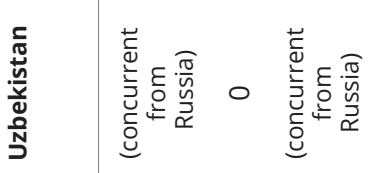

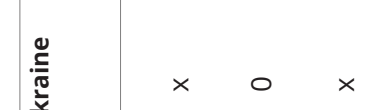

ป

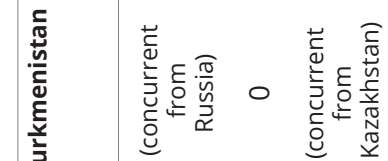

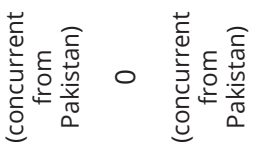

을

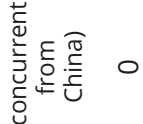

Ơ

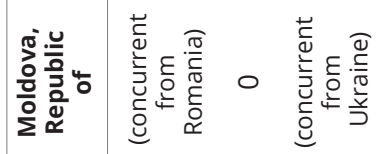

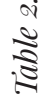

㟧

倞

产

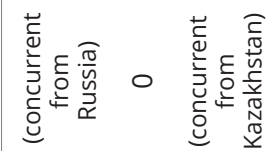

달

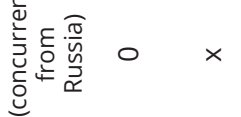

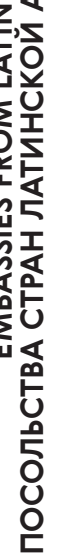

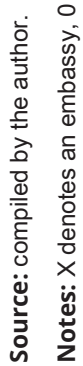

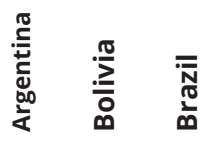




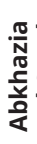

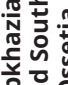

000000000000000

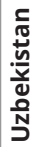

$\circ 00$.

章

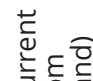

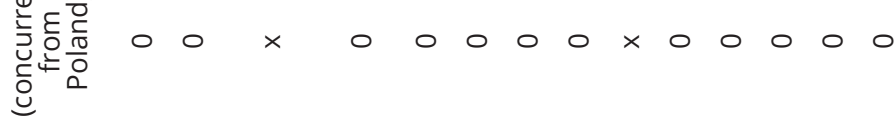

焉

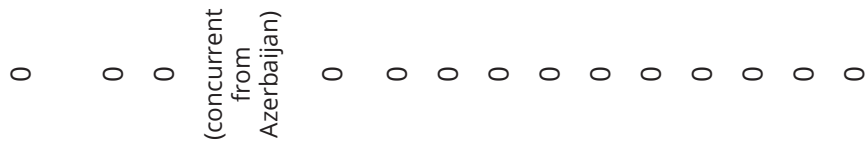

莺

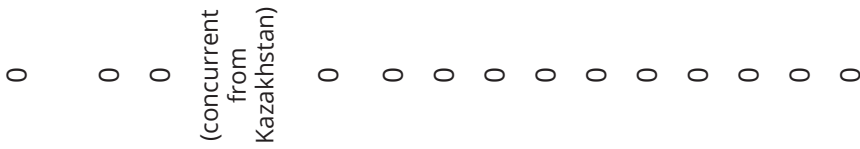

$\stackrel{\leftarrow}{\frac{1}{2}}$

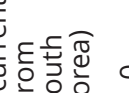

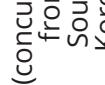

宅늠

응 응 눙

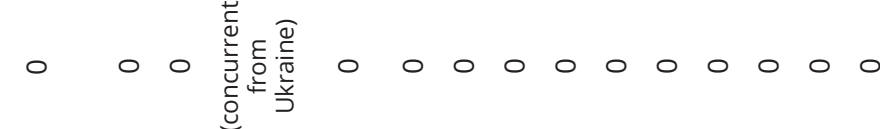

屁

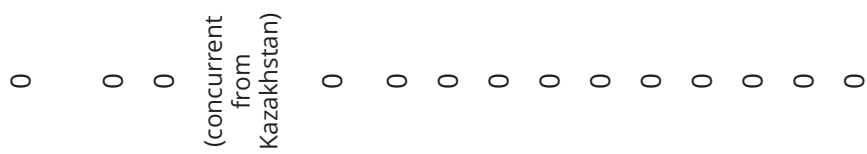

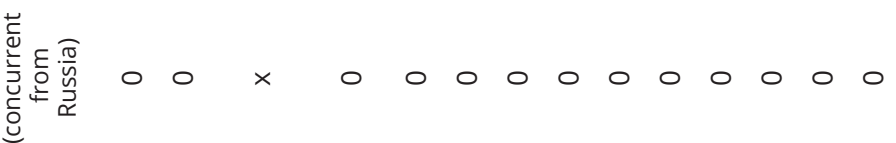

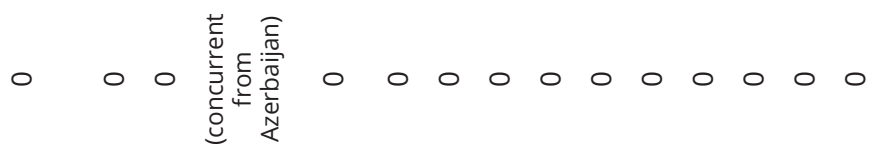

$\frac{2}{\frac{\pi}{0}}$

$000 \times 000000000000$

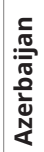

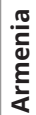

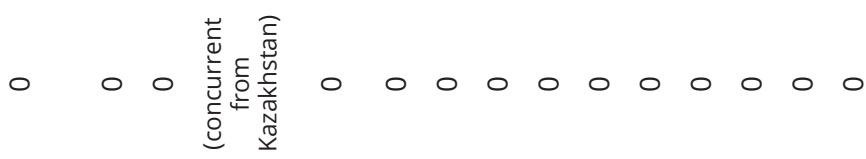

$\times \times \times \times 000000 \times 00000$ 
foreign policy and interest in having a positive image across the world. Thus, NurSultan has opened embassies in Brazil, Cuba, and Mexico, in addition to a consulate in Rosario (Argentina). ${ }^{1}$ This makes sense, as Brazil has sold aircraft to Kazakhstan and is South America's leading state, there is a historical link with Cuba, and Mexico is an economic powerhouse that borders the United States. Interestingly, none of the other four Central Asian nations have diplomatic offices in Latin America or the Caribbean (not even in Cuba) - this puts Nur-Sultan ahead of Tashkent in the competition between the two nations to become a Central Asian leading power. As for Mongolia, it only has an embassy in Cuba, while the Republic of Moldova has no embassies at all, except for an honorary consulate in Brazil.

\section{Many National Interests but Few Long-Term Plans}

Much can be said about the current status of relations between these regions. One way to look at the situation is whether peripheries approaching other peripheries is part of a long-term strategy to achieve some sort of objective.

One nation that values the importance of having diplomatic ties with distant nations is the Republic of Kazakhstan. After establishing relations with Barbados in 2018, Kazakhstan has now established diplomatic relations with all Latin American and Caribbean nations. ${ }^{2}$ The nation's three embassies in the region, while they may appear few to many readers, are actually more than any other Central Asian country possesses. On the other hand, highranking visits are very rare, though Venezuelan President N. Maduro visited Nur-Sultan in September 2017 to participate in a meeting of the Islamic Cooperation Organization. ${ }^{3}$ As for trade and commercial partnerships, in 2017, Kazakhstan's Air Astana acquired five E190E2 commercial aircraft, produced by Brazil's aerospace conglomerate EMBRAER. ${ }^{4}$ Air Astana did not purchase the planes directly from the Brazilian company but rather signed a longterm lease agreement with AerCap; nevertheless, the decision to utilize EMBRAER platforms could promote future deals. ${ }^{5}$ More recently, in 2019, Argentina and Kazakhstan signed an agreement so that Argentina could export cattle semen and embryos to the Central Asian nation to strengthen its cattle industry. ${ }^{6}$ These initiatives generally support an argument made in 2016 by G. Levaggi, who argued that the Nur-Sultan's interest in Latin America and the Caribbean is focused on "continuous interest to increase the political cooperation both in bilateral and multilateral terms," and "investing in the establishment of trade networks."

1 "Presentaron el Consulado de Kazajistán en Rosario (The Consulate of Kazakhstan in Rosario has been Opened)," Concejo Municipal de Rosario (Argentina), August 31, 2017, accessed January 25, 2021, http://www.concejorosario.gov.ar/presentaron-elconsulado-de-kazajstan-en-rosario/

2 "Kazakhstan Completes Establishment of Diplomatic Relations with all Latin American Countries," The Astana Times, April 4, 2018, accessed January 25, 2021, https://astanatimes.com/2018/04/kazakhstan-completes-establishment-of-diplomatic-relations-withall-latin-american-countries/.

3 "Presidente Maduro llega a Kazajistán Para Participar en Cumbre (President Maduro Arrives in Kazakhstan to Participate in Summit)," Telesur, September 9, 2017, accessed January 20, 2021 https://www.telesurtv.net/news/Presidente-Maduro-llega-aKazajistan-para-participar-en-cumbre-20170909-0055.html

4 "Air Astana Orders five Embraer E190-E2s," Russian Aviation Insider, August 2, 2017, accessed January 25, 2021, http://www. rusaviainsider.com/air-astana-orders-five-embraer-e190-e2s/.

5 "Air Astana Leases five E190-E2s from AERCAP," Air Astana, August 2, 2017, accessed January 25, 2021, https://airastana.com/kaz/ en-us/About-Us/Archive/newsID/566.

6 "Argentina Exportará Semen y Embriones de Ganado Bovino a Kazajstan (Argentina to Export Cattle Semen and Embryos to Kazakhstan)," Ministry of Foreign Affairs of Argentina, July 19, 2019, accessed January 30, 2021, https://www.argentina.gob.ar/ noticias/argentina-exportara-semen-y-embriones-de-ganado-bovino-kazajstan.

7 González Levaggi 2016, 80. 
As for positive publicity, the Mexican daily El Universal published a flattering piece about Kazakhstan's interests in Latin America in 2017, which included an interview with Kazakhstani deputy foreign affairs minister, Y. Ashikbayev. ${ }^{1}$

Kazakhstan is the only Central Asian nation to have obtained a non-permanent seat in the UN Security Council (2017-2018) and aims to become one of the 30 most developed nations by 2050. Given its grandiose plans, Nur-Sultan aims to have a strong regional presence; thus, even if a trade is minimal, beating its Central Asian neighbors at having strong relations with Latin American and Caribbean states is significant from an international image perspective and long-term planning. On the other hand, some decisions are made with a focus on short-term gains. One example is the recognition of Abkhazia and South Ossetia as independent states by the governments of Nicaragua and Venezuela. ${ }^{2}$

In fact, in January 2019, when President N. Maduro commenced another term as president of Venezuela, A. Bibilov and R. Khajimba, de facto presidents of Abkhazia and South Ossetia, respectively, traveled to Caracas to attend the inauguration ceremony. ${ }^{3}$ The visit also included a meeting between President A. Bibilov and Venezuelan VicePresident D. Rodríguez, though it is unclear what issues they discussed, apart from that, the two sides evaluated cooperation agreements.

Interestingly, while Managua and Caracas recognize Abkhazia and South Ossetia as independent nations, neither Latin American country has opened embassies or consulates in either separatist region. As mentioned in the Embassy section of this analysis, Venezuela's embassy in Russia is concurrent to the two regions.

Contact between these governments is generally scarce at the high-profile level, apart from the aforementioned 2019 visit and 2010 visit by then-Presidents S. Bagapsh and E. Kokoity of Abkhazia and South Ossetia, respectively, to Caracas and Managua. ${ }^{4}$ One recent development took place in 2019 when the Nicaraguan parliament ratified a visa-free agreement with South Ossetia ${ }^{5}$, and Abkhazian minister of foreign affairs K. Daur visited Managua in July 2021. ${ }^{6}$ However, trade between Nicaragua and Venezuela with the two separatist regions appears to be non-existent. Overall, it seems that neither Nicaragua nor Venezuela benefit directly from having relations with the tiny breakaway regions. Rather, the real reason why Caracas and Managua decided to recognize them was to strengthen relations with Moscow, particularly due to the friendship between President V. Putin and the late-President H. Chávez (1999-2013).

1 Rosa Xochiketzalli, “Kazajistán Busca Acercarse a Latinoamérica (Kazakhstan Seeks Closer Relationship with Latin America),” El Universal, November 1, 2017, accessed January 29, 2021, https://www.eluniversal.com.mx/mundo/kazajistan-busca-acercarselatinoamerica; Wilder Alejandro Sánchez, "The Eurasian Economic Union and Latin America: What could 2018 Bring?" International Policy Digest, December 11, 2017, accessed January 29, 2021, https://intpolicydigest.org/2017/12/11/the-eurasian-economicunion-and-latin-america-what-could-2018-bring/.

2 "Nicaragua Recognizes South Ossetia, Abkhazia," Reuters, September 3, 2008, accessed January 12, 2021, https://www.reuters. com/article/us-georgia-ossetia-nicaragua/nicaragua-recognizes-south-ossetia-abkhazia-idUKN0330438620080903.

3 Wilder Alejandro Sánchez, "Befriending States That Don't Exist: The Leaders of South Ossetia and Abkhazia Visit Venezuela," Diplomatic Courier, January 22, 2019, accessed January 15, 2021, https://www.diplomaticourier.com/posts/befriending-statesthat-dont-exist-the-leaders-of-south-ossetia-and-abkhazia-visit-venezuela.

4 Yolanda Valery, "Abjasia y Osetia buscan reconocimiento en Latinoamérica (Abkhazia and Ossetia Seek Recognition in Latin America)," BBC Mundo, June 22, 2010, accessed January 18, 2021, https://www.bbc.com/mundo/america_latina/2010/07/100722_ venezuela_abjasia_osetia_rg.

5 "Parlamento de Nicaragua Autoriza Acuerdo de Libre Visado con Osetia del Sur (Nicaraguan Parliament Authorizes visa-free Agreement with South Ossetia)," EFE/ El Diario (Spain), September 20, 2019, accessed January 20, 2021, https://www.eldiario.es/ politica/parlamento-nicaragua-autoriza-osetia-sur_1_2721766.html.

6 "Presidente de la Asamblea Nacional Recibe Visita de la Delegacion de la Republica de Abjasia (Speaker of the National Assembly Receives Visit of the Delegation of the Republic of Abkhazia)," Asamblea Nacional (Nicaragua), July 20, 2021, https://noticias. asamblea.gob.ni/presidente-de-la-asamblea-nacional-recibe-visita-de-la-delegacion-de-la-republica-de-abjasia/. 
While Kazakhstan's approach of Latin America and the Caribbean is part of NurSultan's grand long-term strategy of becoming a Central Asian leading power with global connections, including among peripheral nations, the reasons for Nicaragua and Venezuela to approach two post-Soviet new "states" is due to Managua's and Caracas' interest of immediately strengthening ties with Moscow, rather than the potential direct benefits of recognizing two separatist regions.

Diplomatic relations have as a natural consequence that governments may become embroiled in the conflicts of other states, purposely or accidentally. One good example of this situation is the border dispute between Armenia and Azerbaijan over the Nagorno-Karabakh region. A short-lived war occurred in September-November 2020, and the dispute between the two countries has reached Latin America. ${ }^{1}$ For example, in 2012, then-foreign affairs minister of Armenia, E. Nalbandian, visited Mexico City to “reproach Mexico's senadores [senators - author] and diputados [deputies - author] for passing supposedly anti-Armenian resolutions in the past, and proposed an Armenian embassy in Mexico City as the way to help set things right." ${ }^{2}$ Years later, in 2017, three Mexicanfederal deputies, M.B.C. Domínguezfrom the National Regeneration Movement Party (Movimiento Regeneración Nacional: MORENA), M.C.G. Bravo and C.H. Mirón from the Democratic Revolutionary Party (Partido de la Revolución Democrática: PRD), visited Nagorno-Karabakh without reportedly requesting permission from the Azerbaijani government. Baku subsequently presented a complaint to the Mexican government. Shortly after the incident, diplomats from both Armenia and Azerbaijan gave interviews to the well-known Mexican newspaper El Universal to support their government's positions. ${ }^{3}$ While both Armenia and Azerbaijan have embassies in Mexico, the Mexican government has only opened an embassy in Baku, not in Yerevan.

As G. Levaggi argued back in 2016, “Azerbaijan's regional policy towards Latin America has a triple aim: to gain global diplomatic support for the territorial claim, to balance the Armenian lobby, and to expand commercial ties by placing Baku as a gateway to the Caucasus and Central Asia." ${ }^{4}$ At the time of this writing, there have not been any notable diplomatic initiatives from Baku or Yerevan in Latin America after the 2020 conflict; however, we can expect this to occur eventually.

One final issue that the consulted academic literature has not discussed is the role of the media and marketing campaigns, a role that often falls on the shoulders of embassies. It is worth noting again that the three instances discussed in this section of diplomats giving interviews to local media outlets (Armenia, Azerbaijan, and Kazakhstan) all occurred in Mexico. I have not found other instances of ambassadors giving interviews that obtained mainstream coverage in the countries where they work, but this issue, along with other public diplomacy-type events that embassies carry out, should be researched more than solely the visits of high-profile government officials from one region to the other.

González Levaggi et al. 2018, 51-81.

2 Giorgi Lomsadze, "Armenia, Azerbaijan: Face-Off in Mexico Over el Nagorno-Karabaj (Armenia and Azerbaijan face off in Mexico over Nagorno-Karabakh)," Eurasianet, October 23, 2012, accessed February 1, 2021, https://eurasianet.org/armenia-azerbaijanface-off-in-mexico-over-el-nagorno-karabaj.

3 “Armenia Manipulated Mexican Lawmakers in Nagorno-Karabakh, says Azerbaijani Diplomat," El Universal, February 7, 2018, accessed February 1, 2021, https://www.eluniversal.com.mx/english/armenia-manipulated-mexican-lawmakers-nagornokarabakh-says-azerbaijani-diplomat.

4 González Levaggi 2016, 76. 
This section has explained how diplomatic relations between Latin America and post-Soviet states exist, but there are differences between the objectives that states of these regional governments seek to achieve. While some nations like Kazakhstan use diplomatic ties as a way to demonstrate their global outreach, others like Venezuela and Nicaragua use them to strengthen relations with the global power. Similarly, diplomatic allies, even peripheral nations in the global order, can be helpful to support a nation's own domestic objectives, as demonstrated by the Armenia-Azerbaijan dispute or Georgia's claim over Abkhazia and South Ossetia.

\section{A Lack of Trade}

Trade is existent, but no Latin American or Caribbean state ranks as a postSoviet nation's major trading partner, or vice-versa. For example, between JanuaryMay 2021, Moldova exported $\$ 27,000$ goods to Peru and imported $\$ 714,000$; on the other hand, Moldova exported $\$ 432,000$ to reclusive Turkmenistan and imported $\$ 675,000$. $^{1}$ Trade between Moldova and Brazil is better $(\$ 303,000$ in exports and $\$ 3,5$ million in imports), but it is still far from trade with Belarus ( $\$ 26$ million in exports and $\$ 47$ million in imports). Ironically, while Brazil has a strong, varied industry and Belarus is labeled as "Europe's last dictatorship," trade with the latter is stronger than with the former.

Similarly, Mexico and Azerbaijan traded $\$ 43,7$ million in goods during January-October 2020, making Mexico, another rising global market, only the 73rd destination for Azerbaijani markets. ${ }^{2}$ The main Mexican exports to Azerbaijan are oil and vehicles, which also highlights the limited number of diverse goods and commodities traded between these countries. ${ }^{3}$ There have already been examples of Western Hemisphere governments approaching the EAEU. For example, the Cuban government has obtained observer status, and, in 2015, Chile and the EAEU signed a Memorandum of Understanding. ${ }^{4}$ Chilean government officials have expressed that they would like to see more trade, and perhaps a trade agreement, with the EAEU. ${ }^{5}$ Similarly, the Ecuadorian ministry of foreign affairs has expressed its interest in signing a commercial agreement with the said bloc, apart from strengthening ties with Russia. ${ }^{6}$ As for concrete examples of trade, La Paz announced in September 2020 that it would start exporting meat to EAEU states.

1 "International Trade in Goods - January/May 2021," National Bureau of Statistics, Republic of Moldova, accessed August 11, 2021, https://statistica.gov.md/category.php?l=ro\&idc=336.

2 «Мексика является вторым торговым партнером Азербайджана среди стран Латинской Америки» // Тrend. 22 декабря 2020. [Электронный доступ]. URL: https://www.trend.az/azerbaijan/society/3353784.html (дата обращения: 14.02.2021).

3 «Мексика - одна из главных торговых партнеров Азербайджана среди стран Латинской Америки» // Азербайджанское государственное информационное агентство. 20 августа 2020. [Электронный доступ]. URL: https://azertag.az/ru/xeber/ Meksika_odna_iz_glavnyh_torgovyh_partnerov_Azerbaidzhana_sredi_stran_Latinskoi_Ameriki-1565449 (дата обращения: 14.02.2021).

4 "Chile y la Unión Económica Euroasiática dan Primer Paso Hacia un acuerdo comercial (Chile and Eurasian Economic Union Take First Step Towards Trade Agreement)," Ministry of Foreign Affairs of Chile, accessed January 10, 2021, https://chile.gob.cl/chile/ blog/rusia/moscu/chile-y-la-union-economica-euroasiatica-dan-primer-paso-hacia-un-acuerdo.

5 "Chile Apuesta por Impulsar un Tratado de Libre Comercio con la Unión Euroasiática (Chile is Committed to promoting a Free Trade Agreement with the Eurasian Union)," Sputnik Mundo, September 30, 2019, accessed February 1, 2021, https://mundo. sputniknews.com/economia/201909301088833937-chile-apuesta-por-impulsar-tratado-de-libre-comercio-con-la-unioneuroasiatica/.

6 "Ecuador y Rusia Fortalecen Relación Bilateral en Materia de Comercio y Cooperación (Ecuador and Russia Strengthen Bilateral Trade and Cooperation Relationships)," Ministry of Foreign Affairs of Ecuador, October 13, 2020, accessed January 5, 2021, https:// www.cancilleria.gob.ec/2020/10/13/ecuador-y-rusia-fortalecen-relacion-bilateral-en-materia-de-comercio-y-cooperacion/. 
The deal will "directly benefit thousands of Bolivian exporters, entrepreneurs, and workers of the [Bolivian meat - author] industry." 1

For years there have been discussions about some type of agreement between the EAEU and the South American trade bloc MERCOSUR. In fact, in late November 2020, Russian Foreign Affairs Minister S. Lavrov explained that Latin American nations, including MERCOSUR, are interested in close cooperation with the EAEU. As we have mentioned, some academics have also proposed a trade agreement between the two sides, with relations between Argentina and Russia as the catalyst. Nevertheless, it is unlikely that a major agreement will be signed anytime soon, particularly because MERCOSUR currently is at a standstill due to the COVID-19 pandemic and the situation in Venezuela.

\section{Discussion: Where Do We Go from Here?}

Let us begin with a self-evident statement: apart from the Russian Federation, relations between the analyzed regions are fairly limited. The aforementioned Eurasia y América Latina en un Mundo Multipolar concurs with this assessment, arguing that "it is not possible to talk about a Eurasian presence or influence in the region as a unified entity with a homogeneous weight, and we must distinguish between bilateral and multilateral policies."2

As previously mentioned, these three regions are generally labeled as peripheral, as they have limited influence in global affairs - only a few regional powers have extraregional influence and ambitions; Brazil and Kazakhstan are two examples. Academic literature on peripheries and emerging powers tend to focus on the relations between peripheral nations and global powers and what actions peripheral nations can carry out to become bigger players in global affairs, meaning how they can elevate their status vis-à-vis global powers. ${ }^{3}$ Meanwhile, the academic literature regarding how these "peripheries" interact with each other is limited, like the aforementioned works on Latin America's relations with Africa or the Arab World, and less than a handful of essays on Latin America's relations with the post-Soviet space. ${ }^{4}$

Tables 1 and 2 in the Embassy section of this paper have demonstrated how there are several embassies from countries in region $X$ located in countries from region Y. However, the data can be misleading. While the number of embassies appears significant, the locations tend to be the "usual suspects." For example, the location of embassies from post-Soviet states is regional powers like Argentina, Brazil, and Mexico, with Cuba benefiting from its close relations with the USSR during the Cold War as a reason to maintain close ties with post-Soviet states. After Russia, Ukraine is the post-Soviet state that has the most embassies in Latin America and the Caribbean, but the country is an exception to the rule. Moreover, in spite of the number of embassies, Latin America ranks as "secondary" to Kyiv, with the region sometimes

\footnotetext{
1 “Bolivia Exportará Carne Bovina a Países De La Unión Económica Euroasiática (Bolivia to Export Beef to Eurasian Economic Union Countries)," Ministry of Foreign Affairs of Bolivia, September 26, 2020, accessed January 4, 2021, https://www.cancilleria.gob.bo/ webmre/comunicado/3986.

2 Serbin 2019, 148-149.

3 Eszterhai, Renxin 2020.

4 The exception is the wealth of academic literature any policy analyses about relations between Brazil and Africa. See: História da África e Relações com o Brasil, 2018.
} 
not even appearing in Ukraine's national security doctrines over the course of various years.

Overall, the vast majority of countries that were analyzed do not have embassies or diplomatic offices in the other regions, as exemplified by Bolivia, Central America (except for a Costa Rican embassy in Azerbaijan), Central Asia (apart from Kazakhstan), Paraguay, Peru, Moldova, and Uruguay. While governments may have cordial, diplomatic relations without having embassies, these are important agencies to have in situ, as a critical role for embassies, consulates, and other diplomatic offices are to constantly promote relations between states and project the interests and objectives of the visiting nation to host-state officials, businesses and the general population.

Yet how effective these foreign missions have been at promoting their home government's interests, such as trade or foreign policy objectives, in the host nation? I have already mentioned how some diplomats have been interviewed by local newspapers or met with local government officials to promote their country's interests (e.g. Armenia, Azerbaijan, and Kazakhstan); however, greater research is required to properly answer this question in each circumstance. Public diplomacy initiatives also deserve greater research.

As for specific countries, the Venezuelan government's strong ties with Russia for the past two decades have trickled down to cordial relations with Belarus and even recognition of Abkhazia and South Ossetia. However, this trend is very dependent on the continuation of President N. Maduro in power. The Georgian government has met with President J. Guaidó, Venezuela's self-proclaimed president, and Tbilisi actually recognizes J. Guaidó as president. The case of Azerbaijan and Armenia is quite curious as these two countries, particularly Azerbaijan, have several embassies in the Western Hemisphere; however, there is no trade turnover. The purpose of these diplomatic ties may be to maintain cordial relations and seek support for their causes regarding the Nagorno-Karabakh issue. The aforementioned diplomatic faux pas involving Mexican members of congress demonstrates how a diplomatic visit or misplaced comments by a government official can provoke a strong response from Baku and Yerevan.

Cross-regional trade exists, but it is not particularly significant. Trade generally falls under the categories of energy products such as oil, chemicals, or construction equipment. Food products like meat are also exported. While discussing economic integration and trade with post-Soviet Eurasian nations, "one of the other obstacles on the path of the foreign trade for the countries in the region is their geographical positions. The fact that the primary commercial partnerships are in other regions prevents the establishment of an effective commercial route." ${ }^{11}$ The case of Moldova is a good example, as the tiny country trades more with Belarus than Brazil. Similarly, Ukraine's major trade partners in Latin America are Argentina, Brazil, and Mexico, which represented, pre-2014 crisis, some 80\% of Ukraine's overall trade with the region. ${ }^{2}$ Again, geography is at fault, as transportation can be costly, delivery times are significant, and the potential revenue is low, particularly since we are talking about 
mostly developing regions." "Business circles [in] Ukraine and Latin America do not know each other well enough," explains K. Kurylev, and the same can be said about other nations. ${ }^{2}$

Will there be more trade or diplomatic initiatives in the future? Unlikely, one possibility is that a third party brings these regions together. For example, Russia can host a major summit with Latin American and Caribbean policymakers and business leaders. This is not unprecedented as it already took place in 2019 with the RussiaAfrica summit. A similar mega-gathering in Moscow or Saint Petersburg could bring representatives from Azerbaijan, Armenia, Belarus, Mongolia, and Central Asian states to meet with their Western Hemisphere counterparts to encourage dialogue and perhaps trade.

\section{Conclusion}

I conclude that as a new decade commences in a post-Cold War, globalized world, Latin America, the Caribbean, and post-Soviet states in Eastern Europe, the Caucasus, and Central Asia remain being cordial strangers. This analysis has provided data that has not been discussed at length in other research, like, for example, the number of embassies in different countries, in order to demonstrate which countries are regarded as priorities by other governments across the world. Public diplomacy initiatives, media interviews, and academic publications published in region $X$ that address relations with region $Y$ have also been discussed - in these areas, the Mexican media has published interviews in recent years with diplomatic officials from post-Soviet nations, while Kazakhstan is taking the lead in Central Asia regarding studies with Latin America. As this essay has discussed 33 nations in Latin America and the Caribbean and 11 nations in the post-Soviet world (apart from Russia and the Baltic states plus Mongolia), the amount of interactions between these regions in the past three decades, since the dissolution of the Soviet Union, is quite limited and not conducive to strong partnerships.

The lack of relations between Latin America, the Caribbean, and post-Soviet states is an example of geographically distant regions that are slowly developing diplomatic and trade relations. The countries involved in this study are a mix of medium regional powers and small nations, many of which have very limited financial assets and lack an ambitious foreign policy. It is understandable that for several governments, the possibility of approaching distant states that will not provide significant benefits (e.g., trade, financial assistance, or diplomatic support) is not a worthy cost, thus focus is given to befriending global powers, medium powers, and blocs.

In the globalized world of the $21^{\text {st }}$ century, what are the components necessary to make diplomacy evolve between small and medium regional powers, the so-called periphery of the global order? This has been the crux of the academic question this essay has addressed. As the case of Latin America, the Caribbean, and the postSoviet nations across Eastern Europe, the Caucasus, and Central Asia demonstrates, establishing diplomatic relations with new states can be easy, but developing 
meaningful partnerships is complicated for governments that lack the foresight, interest, and resources to achieve them.

\title{
СПИСОК ЛИТЕРАТУРЫ / REFERENCES
}

Курылев, К.П., Мачавариани Г.Г. Развитие отношений между докризисной Украиной и Латинской Америкой // Журнал политических исследований. - 2017. - Том 1 (3). - С. 101-122.

Kurylev, K.P., and G.G. Machavariani “Razvitie otnoshenij mezhdu dokrizisnoj Ukrainoj i Latinskoj Amerikoj." Zhurnal politicheskih issledovanij 1, no. 3. (2017): 101-122 [In Russian].

Atik, Selda. "Regional Economic Integrations in the Post-Soviet Eurasia: An Analysis on Causes of Inefficiency." Procedia - Social and Behavioral Sciences 109 (2014): 1326-1335. https://doi.org/10.1016/j. sbspro.2013.12.633.

Botta, Paulo, and A. Zholdasbekova. "Argentina and Kazakhstan Relations." International Scientific-Analytical Journal Мемлекеттик баскару жане кызмет 3, no. 74 (2020): 68-76.

Dallanegra Pedraza, Luis. “Teoría y metodología de la geopolítica: Hacia una geopolítica de la "construcción de poder." Revista Mexicana de Ciencias Políticas y Sociales 53, no. 210 (September-December 2016): 15-42.

Dallanegra Pedraza, Luis. "Theory and Methodology of Geopolitics: Towards Geopolitics of 'Power Construction."' Revista Mexicana de Ciencias Políticas y Sociales 53, no. 210 (September-December 2016): 15-42 [In Spanish].

Eszterhai, Viktor, and Renxin Wang, eds. Stuck Between Great Powers: The Geopolitics of the Peripheries. Geo Institute. Corvinus: University of Budapest, 2020.

González Levaggi, Ariel. “Towards The Peripheries Of The Western World: Eurasian Regional Policies In Latin America." Anuario de Integración 13 (2016): 60-87.
González Levaggi, Ariel, Nilüfer Narli, and Akbota Zholdasbekova, eds. Eurasia-Latin America Strategic Engagement and Comparative Perspectives in Politics and Economics. Astana: L.N. Gumilyov Eurasian National University, 2018.

Haynes, Jeffrey, Peter Hough, Shanin Malik, and Lloyd Pettiford. World Politics: International Relations and Globalisation in the 21st century. Second Edition. Los Angeles: SAGE, 2017.

História da África e Relações com o Brasil. Brazil: Fundação Alexandre de Gusmão, 2018. http://funag.gov. br/loja/download/Historia_da_Africa.pdf.

History of Africa and Relations with Brazil. Brazil: Fundação Alexandre de Gusmão, 2018 [In Portugese].

Tawil Kuri, Marta, ed. Latin American Foreign Policies towards the Middle East. New York: Palgrave Macmillan US, 2016.

Saddy, Fehmy. The Arab World and Latin America: Economic and Political Relations in the Twenty-First Century. I.B. Tauris, 2016.

Serbin, Andrés. Eurasia y América Latina en un mundo multipolar. Spain: Icaria Editorial, 2019. http://www.cries.org/wp-content/uploads/2019/09/ AndresSerbinLibroEURASIA-web.pdf.

Serbin, Andrés. Eurasia and Latin America in a Multipolar World. Spain: Icaria Editorial, 2019 [In Spanish].

Walton, C. Dale. Geopolitics and the Great Powers in the $21^{\text {st }}$ Century. New York: Routledge, 2007.

\author{
Author \\ Wilder Alejandro Sanchez, \\ independent geopolitical and defense analyst, USA. \\ e-mail: wilder.a.sanchez@gmail.com
}

\section{Additional information}

Received: February 24, 2021. Revised: July 26, 2021. Accepted: October 5, 2021.

\section{Disclosure statement}

No potential conflict of interest was reported by the author.

\section{For citation}

Sanchez, Wilder Alejandro. "Latin America and the Caribbean Meet the Post-Soviet World:

Can Pro Forma Diplomacy Evolve?" Journal of International Analytics 12, no. 3 (2021): 154-172.

https://doi.org/10.46272/2587-8476-2021-12-3-154-172 


\title{
Взаимодействие стран Латинской Америки и Карибского бассейна с постсоветским пространством: к вопросу об эволюции дипломатических связей
}

\begin{abstract}
АННОТАЦИЯ
33 страны, составляющие регион Латинской Америки и Карибского бассейна, и 11 стран бывшего Советского Союза (не считая Российской Федерации и трех стран Прибалтики плюс Монголия) находятся на периферии глобальных геополитических процессов с ограниченным международным влиянием или во власти конфликтов, нарушивших их внутреннее равновесие

и международный имидж за последнее десятилетие. Хотя тема того, как периферийные страны и регионы взаимодействуют друг с другом, анализировалась в академических кругах, углубленных исследований отношений между этими конкретными регионами очень мало. Анализ, изложенный в данной статье, направлен на восполнение этого пробела, оперирует примерами из недавнего прошлого по таким вопросам, как торговля и дипломатические обмены между правительствами стран Латинской Америки и Карибского бассейна и их постсоветскими визави. В статье обсуждается вопрос местонахождения (или его отсутствия) посольств: тема, практически не обсуждаемая в исследуемой литературе. Делается вывод, что отсутствие видения большой стратегии является серьезным препятствием для укрепления отношений между государствами исследуемых регионов. Наиболее вероятный сценарий - это межблочные торговые соглашения, однако пандемия COVID-19 и другие насущные проблемы, с которыми сталкиваются эти страны, означают, что соглашения с географически удаленными государствами, которые не являются торговыми партнерами или потенциальными источниками финансовой помощи, не рассматриваются в качестве приоритетов.
\end{abstract}

\section{КЛЮЧЕВЫЕ СЛОВА}

Латинская Америка, Карибский бассейн, постсоветское пространство, дипломатия, торговля, Центральная Азия, Кавказ

\section{Сведения об авторе}

Уайлдер Алехандро Санчес, независимый исследователь по вопросам геополитики и обороны, США. e-mail: wilder.a.sanchez@gmail.com

Дополнительная информация

Поступила в редакцию: 24 февраля 2021.

Переработана: 26 июля 2021.

Принята к публикации: 5 октября 2021.

\section{Конфликт интересов}

Автор заявляет об отсутствии потенциального конфликта интересов.

\section{Цитирование}

Санчес, У.А. Взаимодействие стран Латинской Америки и Карибского бассейна с постсоветским пространством: к вопросу об эволюции дипломатических связей // Международная аналитика. - 2021. - Том 12 (3). - С. 154-172. 